\title{
Diversity in the Stem Anatomy and Tissues of Several Species of Annona (Annonaceae) in Nigeria
}

\author{
Abayomi Ezekiel FOLORUNSO \\ Obafemi Awolowo University, Faculty of Science, Department of Botany, Ile-Ife, Nigeria; afolorun@oauife.edu.ng
}

\begin{abstract}
Comparative study of the stem anatomy of Annona trees was carried out to facilitate identification of taxa when their reproductive parts are not available. Stem specimens of four out of the five species categorized as important under-utilized species were collected and subjected to anatomical studies. Macerated materials followed Schutze's method of maceration and the transverse sections of the stem were cut using Reichert Sledge Microtome. Intrageneric characters observed are: epidermal layer uniseriate with round, oval to polygonal collenchyma cells. Wood is diffuse-porous, vessel elements are diffuse, vessels are of two types, that is, short/wide with simple pits and long/narrow with bordered pits. Diagnostic characters for the identification of each of the species are also reported.
\end{abstract}

Keywords: Annona, comparative study, diagnostic characters, intrageneric characters, stem anatomy

\section{Introduction}

Annona is a genus of tropical fruit tree belonging to the family Annonaceae (Nakasone and Paull, 1998). It has approximately 119 species of which seven and one hybrid are grown for domestic/commercial use. Five species have been selected as important under-utilized species (ICUC, 2002).

Economically, Annona trees can be categorized into two groups. In the first group are $A$. reticulata (custard apple) and $A$. senegalensis (wild soursop) which are grown by subsistence farmers under small holder conditions, resulting in low income to their growers. The second group includes $A$. muricata (soursop) and $A$. squamosa (sugar apple) which are grown in commercial farms as highly remunerative crops for both small and medium scale farmers (Vogt, 1995). Annonas are generally consumed as fresh fruits, but are also widely used in semi-processed and processed products (Salunkhe and Desai, 1986). Based on their nutritional status, $A$. reticulata and $A$. squamosa have been reported to have more nutritional (protein) and shelf-life than $A$. muricata and $A$. senegalensis (Folorunso and Modupe, 2007).

Suffice to say that a number of studies had been carried out on the genus Annona, there had been no report on the diversity of the stem anatomy and tissues of Annona trees. Olatunji (1992) in his work on the wood anatomy of some species of Zanthoxylum in Nigeria reported that despite the close similarities observed among the species in many of their wood anatomical features, some of the species possess specific features which may be employed to delimit them. Studies of this nature might facilitate identification of taxa most importantly when their reproductive parts are not available. And of course, this would enable both taxonomists and the general public to have inkling of this plant and as such harness all possible means of conserving them. In the present paper, the stem anatomy and tissues of four species of Annona is described and compared.

\section{Materials and methods}

Stem samples of four out of the five species categorized as important under-utilized species were collected within the experimental garden of Obafemi Awolowo University Campus, Ile-Ife, Nigeria. They are : A. muricata (soursop), $A$. senegalensis (wild soursop), $A$. reticulata (custard apple) and $A$. squamosa (sugar apple). The stem samples of the species investigated were kept as voucher specimen in the Herbarium, Department of Botany, Obafemi Awolowo University, Ile-Ife (IFE).

Small blocks of wood, about $1 \mathrm{~cm} \times 1 \mathrm{~cm} \times 1 \mathrm{~cm}$ were removed from the trunk of the trees of about 1.5 metres from the ground. The blocks were macerated following Schutze's method of maceration. This method of maceration involves the addition of fuming concentrated trioxonitrate (v) $\left(\mathrm{HNO}_{3}\right)$ into test tubes to a level just above the contained match-stick size wood samples. Few crystals of solid Potassium Chromate $\left(\mathrm{K}_{2} \mathrm{Cr}_{2} \mathrm{O}_{7}\right)$ was added. This was then placed on a hot plate for about 4 minutes when the samples must have macerated. Small pieces of the macerated wood were stained in $1 \%$ Safranin 0 and mounted on slide using dilute glycerol as mountant. Anatomical measurements were made in ocular units at $40 \mathrm{X}$ objective power and converted to micrometers. Illustration of the wood anatomical features were done by camera lucida under x 25 objective power of Leitz DIALUX research microscope. 
The blocks of wood were boiled in water for about two hours to soften them. The transverse sections of the stem were cut on a Reichert Sledge microtome at varying thicknesses between 20-30 microns. The sections were stained in Alcian blue, counter stained with Toluidine blue (to enhance contrast) washed thoroughly in water, dehydrated through series of ethyl alcohol : 50, 70, 90, 95\%, cleared in xylene and mounted in D. P. X. mountant. Photomicrographs of the transverse section were made from the photomicrographic outfit fitted to Wild M20 microscope.

\section{Results}

\section{Annona senegalensis}

Epidermal layer uniseriate, collenchyma cells round, oval to polygonal; wood diffuse-porous. Vessels are of two types, short and wide type and the long and narrow type (Tab. 1). They have simple intravascular pits which occur in tiny circular sizes scattered throughout the vessels or some could possess bordered pits arranged in opposite pair. Most vessels that exhibit bordered pits are long with length 162.0-334.8 $\mu \mathrm{m}$ and width of 54.0-126.0 $\mu \mathrm{m}$. Other simple pitted vessels are relatively short with length of 43.3-169.2 $\mu \mathrm{m}$ and width of 21.6-111.6 $\mu \mathrm{m}$. Vessel elements are round, oval to elliptic in radial multiples of 2-5 pores. Vessel diameters are $30 \pm 1.0 \mu \mathrm{m}$. Fibres are non-septate. Fibre-tracheids are 133.2-655.2 $\mu \mathrm{m}$ long and $10.8-25.2 \mu \mathrm{m}$ short, they have blunt ends to tapering ends with thin walls, simple pits which could be scattered to few cluster or slit-like pits which run in an alternate manner across the length of the fibre. Libriform fibres are 586.8-972.0 $\mu \mathrm{m}$ long with very thin width of 3.6-10.8 $\mu \mathrm{m}$. They have very thick walls and sharp tapering ends. Axial parenchyma cells are abundant, paratracheal and short with thin walls and simple pits. They have length of 205.2$406.8 \mu \mathrm{m}$ and average width of 7.2-18.0 $\mu \mathrm{m}$. Ray consists of both uniseriate and multiseriate rays. Ray parenchyma cells are homocellular and scarcely distributed with length of 190.8-367.2 $\mu \mathrm{m}$ and width of 43.2-57.6 $\mu \mathrm{m}$. They have thin walls and simple pits.

\section{Annona muricata}

Epidermal layer uniseriate, collenchyma cells round, oval to polygonal; wood diffuse-porous. The vessels have thin walls and have simple intravascular pits or bordered pits with opposite pair pitting arrangement. Scattered pitted vessels are short with length of 46.8-82.8 $\mu \mathrm{m}$ and width of 14.4-39.6 $\mu \mathrm{m}$. While the opposite pitted vessels are of length 259.2-493.2 $\mu \mathrm{m}$ and width 46.8-115.2 $\mu \mathrm{m}$. Vessel elements are round, oval to elliptic in radial multiples of 2-9 pores. Vessel diameters are $3 \pm 1.5 \mu \mathrm{m}$. Fibres consist of both Libriform fibres and fibre-tracheids. Libriform fibres taking the longest length ranging from 802.8-1011.0 $\mu \mathrm{m}$ and width of 3.6-10.8 $\mu \mathrm{m}$.They have very thick wall and thin lumen. Libriform fibres have sharp tapering ends and are not with pits. Fibre-tracheids are with length of 190.8$662.4 \mu \mathrm{m}$ and width of $14.4-25.3 \mu \mathrm{m}$. They have thin walls and contain scattered pits of circular sizes or slit-like pits arranged in an alternate manner down the fibre. Most fibre-tracheids have tapering ends while others have blunt ends. Axial parenchyma cells are abundant, confluent paratracheal and have thin walls. It contains simple pits and possess blunt ends. They have length of 241.2-908.0 $\mu \mathrm{m}$ and width of 10.8-21.6 $\mu \mathrm{m}$. Ray parenchyma cells are scarcely distributed with thin walls and scattered simple pits. They are multiseriate with a few uniseriate cells and have blunt ends with homocellular cells. They have length of 108.0-385.2 $\mu \mathrm{m}$ and width of 46.8-122.4 $\mu \mathrm{m}$.

Tab. 1. Comparative stem anatomy in some species of Annona in Nigeria

\begin{tabular}{|c|c|c|c|c|}
\hline & A. senegalensis & A. squamosa & A. reticulata & A. muricata \\
\hline Epidermal layer uniseriate & + & + & + & + \\
\hline Collenchyma round oval to polygonal & + & + & + & + \\
\hline Wood diffuse porous & + & + & + & + \\
\hline Solitary vessel generally (10-15\%) or more & + & - & + & + \\
\hline Vessel in radial multiples of $2-5$ pores & + & 2-11pores & + & 2-9pores \\
\hline Vessel round, oval to elliptic & + & + & + & + \\
\hline Vessel diameter & $30 \pm 1.0 \mu \mathrm{m}$ & $35 \pm 1.5 \mu \mathrm{m}$ & $40 \pm 2.0 \mu \mathrm{m}$ & $35 \pm 1.5 \mu \mathrm{m}$ \\
\hline Ray uniseriate with few multiseriate rays & + & + & + & Ray multiseriate \\
\hline $\begin{array}{l}\text { Ray predominantly homocellular } \\
\text { to weakly heterocellular }\end{array}$ & + & + & + & + \\
\hline Ray & $450 \pm 0.001 \mu \mathrm{m}$ long & $400 \pm 0.001 \mu \mathrm{m}$ long & $680 \pm 0.002 \mu \mathrm{m}$ long & $850 \pm 0.003 \mu \mathrm{m}$ long \\
\hline $\begin{array}{l}\text { Axial parenchyma abundant } \\
\text { paratracheal and confluent }\end{array}$ & + & + & + & $=$ \\
\hline Axial parenchyma vasicentric aliform & - & - & + & - \\
\hline Pith diameter & $900 \pm 0.001 \mu \mathrm{m}$ & $600 \pm 0.002 \mu \mathrm{m}$ & $1100 \pm 0.001 \mu \mathrm{m}$ & $500 \pm 0.001 \mu \mathrm{m}$ \\
\hline Tannins & - & - & + & - \\
\hline Fibre/Vessel ratio & $55 / 122$ & $12 / 6$ & $27 / 2$ & $50 / 40$ \\
\hline Average Fibre Length & $401 \pm 0.07$ & $373 \pm 0.03$ & $405 \pm 0.09$ & $434 \pm 0.01$ \\
\hline Average Vessel Length & $82 \pm 0.08$ & $285 \pm 0.08$ & $263 \pm 0.02$ & $61 \pm 0.09$ \\
\hline
\end{tabular}




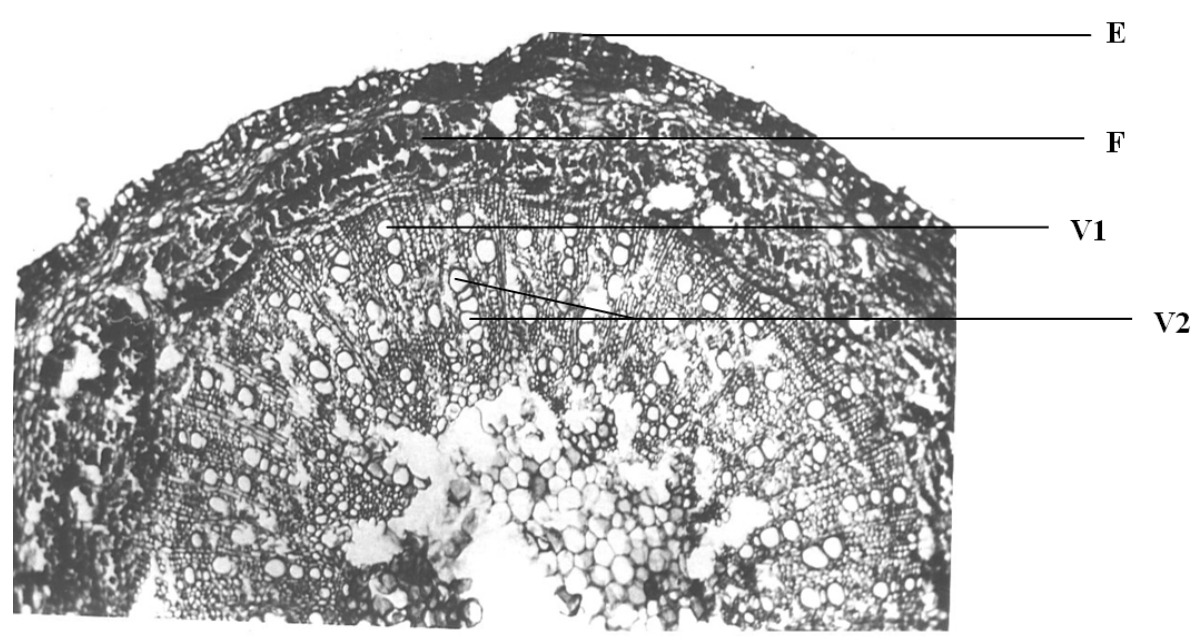

Plate 1. Annona senegalensis; E-Epidermis; F-Fibre; V1-Single vessel; V2-Joined vessels

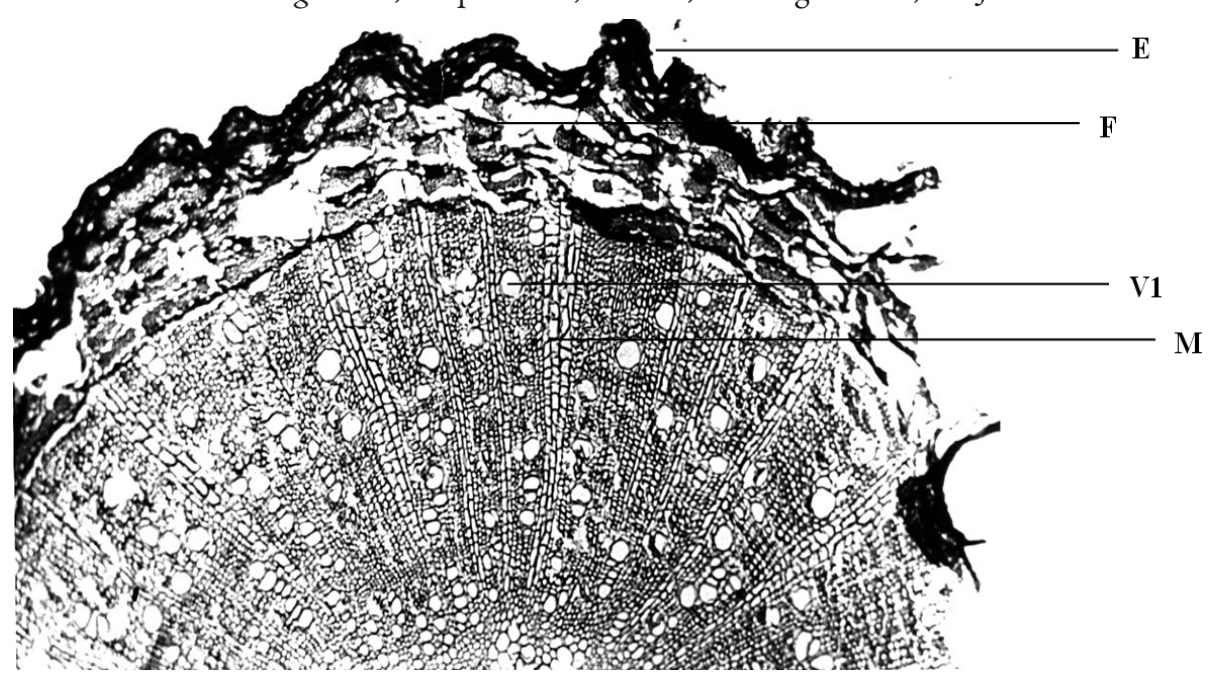

Plate 2. Annona muricata; E-Epidermis; F-Fibre; V1-Single vessel; V2 -Joined vessels; M-Medullary ray

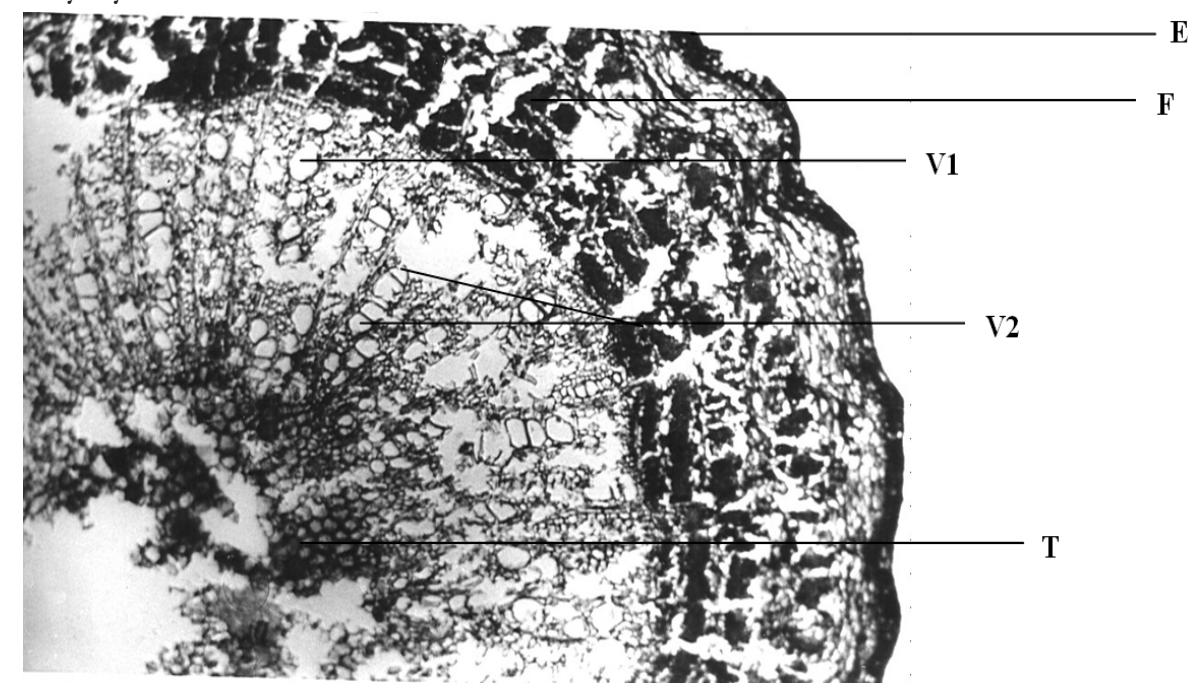

Plate 3. Annona reticulata; E-Epidermis; F-Fibre; V1-Single vessel; V2-Joined vessels; T-Tannin

Annona reticulata

Epidermal layer uniseriate, collenchyma cells round, oval to polygonal; wood diffuse-porous. The vessel member comprises of both the wide and the narrow vessels. The vessels are less abundant than the fibre cells and are evenly distributed throughout the entire length of the wood. The vessels consist of a series of axially superimposed cells whose intervening end walls have been perforated. The vessels are relatively short in length $147.6 \mu \mathrm{m}$ to $360 \mu \mathrm{m}$. The narrow vessels have width of $64 \mu \mathrm{m}$ to $90 \mu \mathrm{m}$ and the 


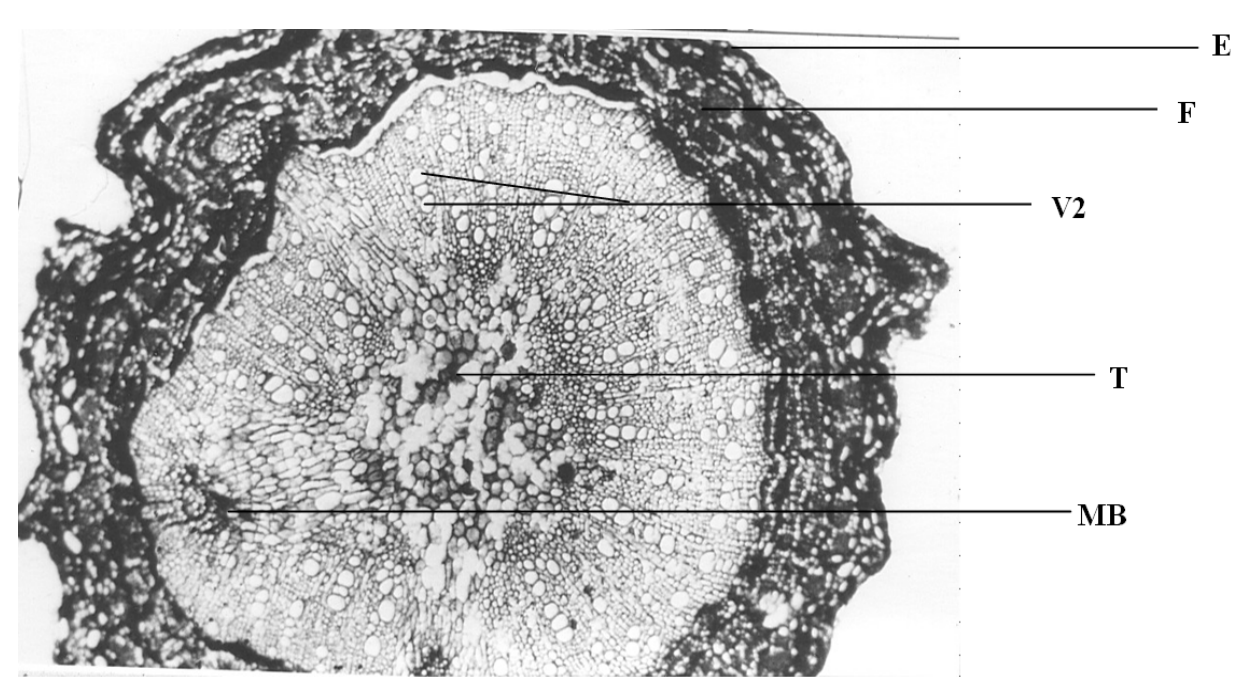

Plate 4. Annona squamosa; E-Epidermis; F-Fibre; V2-Joined vessels; MB-Medullary bundle; T-Tannin

wide vessels on the other hand have width of $133.2 \mu \mathrm{m}$ to $200 \mu \mathrm{m}$. The vessels have a very thin cell wall with the abundance of pits. The pits are either simple or bordered with opposite pitting. Some of the intervascular pits are alternate and bordered; the vessels observed do not have tails at their perforated ends. Vessel elements are round, oval to elliptic in radial multiples of 2-5 pores. Vessel diameters are $40 \pm 2.0 \mu \mathrm{m}$. The fibres are more abundant in the stem of Annona reticulata and are found throughout the entire length of the wood. The fibres, either fibre tracheids or libriform type are longer and narrower than their corresponding vessels and are all tapered towards their ends. Fibre-tracheids $540 \mu \mathrm{m}-600 \mu \mathrm{m}$ long and $43.2 \mu \mathrm{m}$ to $79.2 \mu \mathrm{m}$ short. They are characterised by their long, thin and tapered ends. They are mostly thin walled. Their pits are simple which could be scattered to few clusters or slitlike than runs in an alternating pattern across the length of the fibre. Libriform fibres are always longer and thinner than their corresponding fibre tracheids, the shortest has the dimension of $396 \mu \mathrm{m}$ by $7.2 \mu \mathrm{m}$. Libriform fibres are very scanty in the species of $A$. reticulata and are generally characterised by their thin lumen and thick cell wall. They have few or no pits. The axial parenchyma cells are abundant and confluent paratracheal, they are $160 \mu \mathrm{m}$ to $192 \mu \mathrm{m}$ long and $21.6 \mu \mathrm{m}$ to $36 \mu \mathrm{m}$ short. They are thick walled and have abundance of simple pits scattered on their cell surfaces. The ray parenchyma cells are predominantly homocellular. Their length varying from $54 \mu \mathrm{m}$ to $76 \mu \mathrm{m}$ and with width of $24.8 \mu \mathrm{m}$ to $30 \mu \mathrm{m}$. Osteosclerids are in the pith.

\section{Annona squamosa}

Epidermal layer uniseriate, collenchyma cells round, oval to polygonal; wood diffuse-porous. The vessels occur in horizontal rows, with opposite pitting, they are long with length range of $172.8 \mu \mathrm{m}$ to $342 \mu \mathrm{m}$ and are mostly wide with width range of $64.8 \mu \mathrm{m}$ to $100.8 \mu \mathrm{m}$. The vessels are characterized by their plate-like perforated ends which are wide and almost taking the whole width of the vessel, the perforations are simple and are tailed. Vessel elements are round, oval to elliptic in radial multiples of 2-11 pores. Vessel diameters are $35 \pm 1.5 \mu \mathrm{m}$. Fibres are more abundant than any other cell types in the wood of Annona squamosa. The libriforms are thinner and longer with length ranging from $414 \mu \mathrm{m}$ to $547.2 \mu \mathrm{m}$ and has a width of $17 \mu \mathrm{m}-36$ $\mu \mathrm{m}$. Fibre tracheids are shorter, their length ranges from $272 \mu \mathrm{m}$ to $490 \mu \mathrm{m}$ and has a width of $18 \mu \mathrm{m}$ to $42 \mu \mathrm{m}$. Axial parenchyma abundant, confluent paratracheal, they are thick walled and are found in varying thickness; their length ranges from $184 \mu \mathrm{m}$ to $240 \mu \mathrm{m}$. they have width with the range of $8 \mu \mathrm{m}$ to $17 \mu \mathrm{m}$. They also have abundant pitting system arranged in opposite rows. Ray parenchyma cells are uniseriate except few that are multiseriate and they are less abundant in the wood, they could be as long as 60 $\mu \mathrm{m}$ to $78 \mu \mathrm{m}$ with their width varying from $20 \mu \mathrm{m}$ to 32 $\mu \mathrm{m}$. There are many crystals of Calcium Oxalate scattered in the cells. Osteosclerids are in the pith.

\section{Discussion}

Evidence of common evolutionary origin in the $\mathrm{An}$ nona species had been reported (Folorunso and Olorode, 2006a). According to them, there are intrageneric relationships among the Annonas (Folorunso and Olorode, 2006a, b). In this work, more intrageneric characters are reported. These are epidermal layer uniseriate with round, oval to polygonal collenchyma cells. The wood is diffuseporous, vessel elements are diffuse, and the vessels are of two types, that is, short-wide with simple pits and the long-narrow with opposite pair pitting arrangements of bordered pits. All these characters are reportedly typical of the primitive angiosperms and as such would be useful in their identification. Also, the occurrence of solitary vessels which are more than grouped vessels in all the species of Annonaceae studied is an indication that the family is a primitive one.

The diagnostic characters for both $A$. reticulata and $A$. squamosa are the presence of axial parenchyma which is confluent paratracheal and the presence of osteosclerids in their piths. These two species are reported to have 

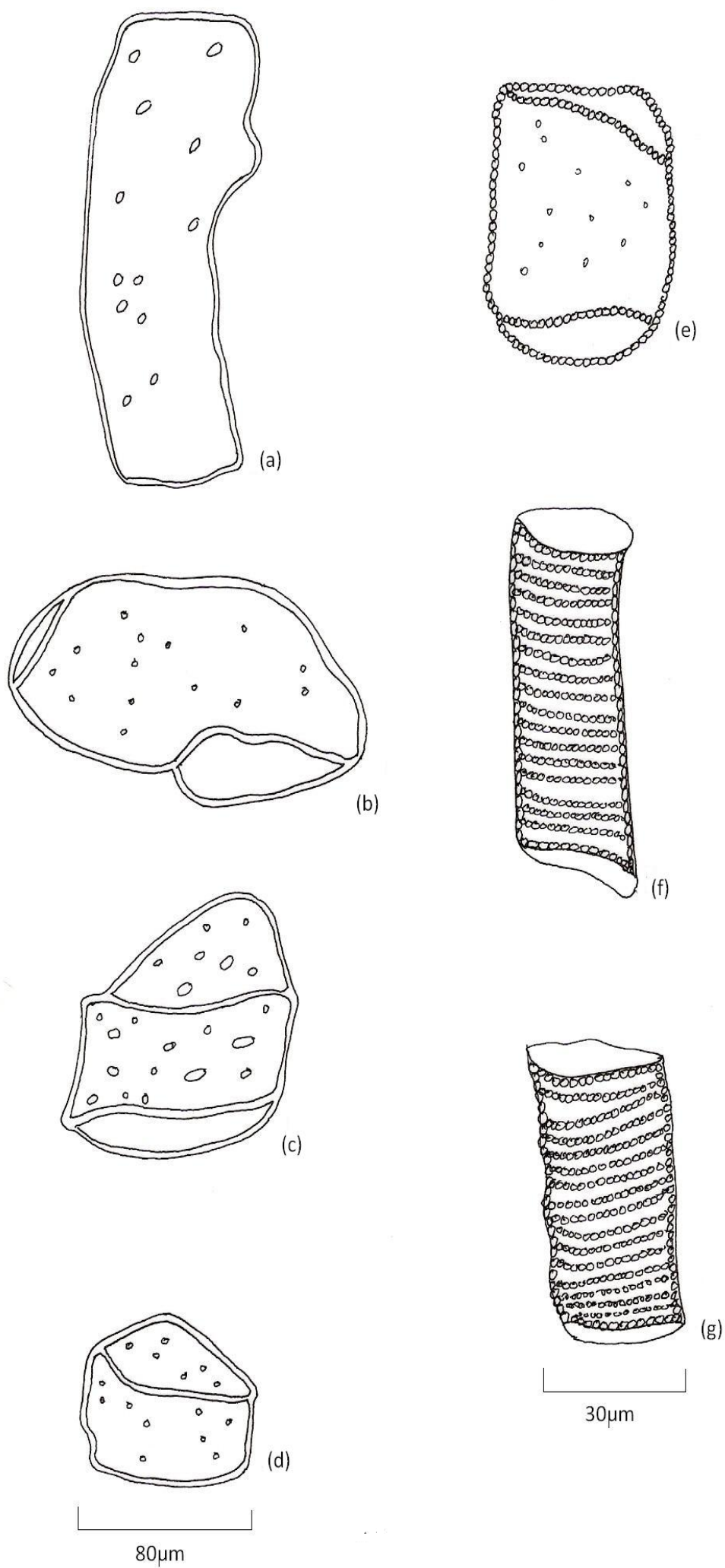

(g)

(d)

Fig. 1. Diagrammatic illustration of vessel types in Anno
Diagram f-g: Narrow vessel types in Annona senegalensis 

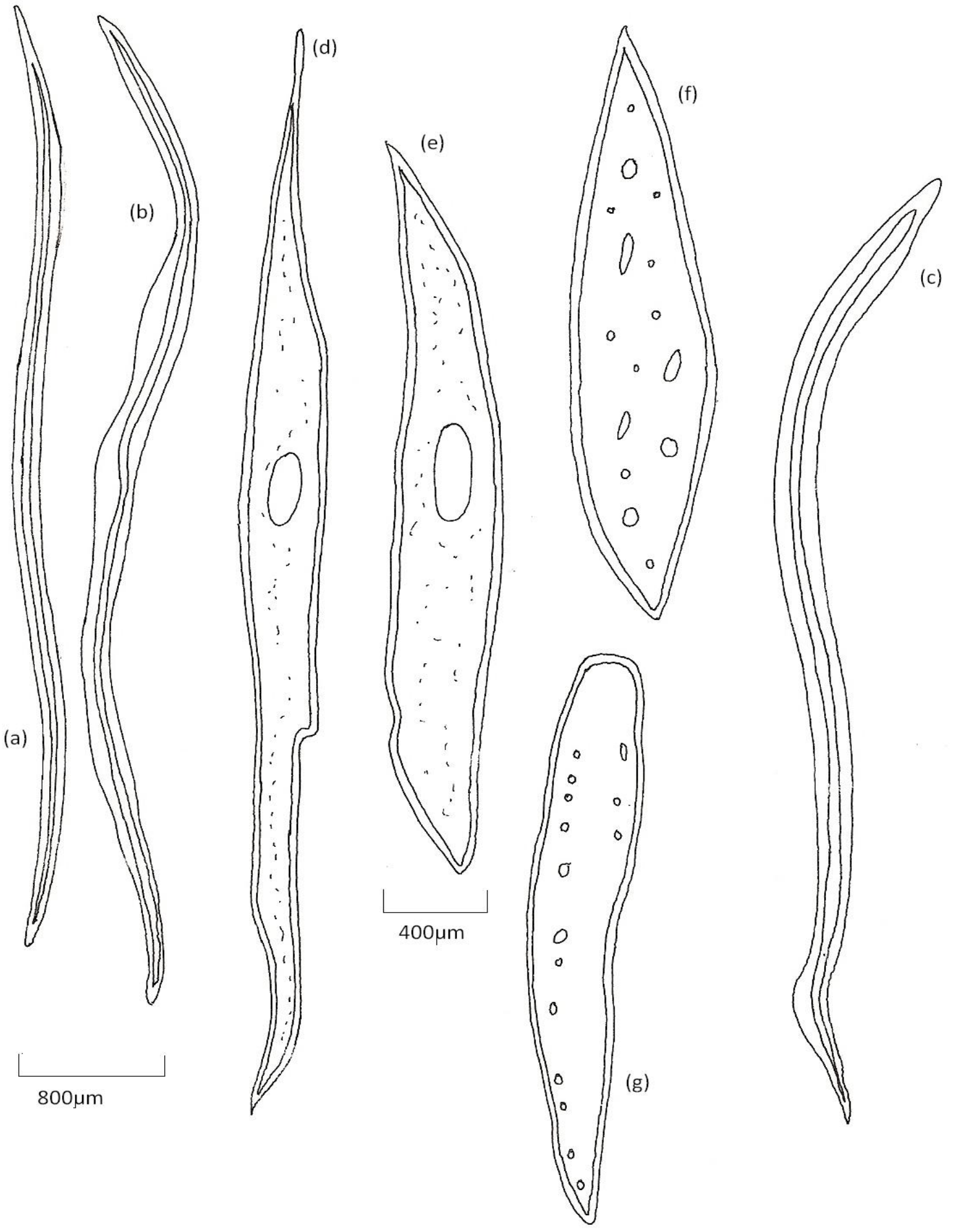

Fig. 2. Diagrammatic illustration of Fibre types in Annona senegalensis; Diagram a-c: Libriform fibres in Annona senegalensis; Diagram d-e: Simple slit-like pitted Fibre-tracheid in Annona senegalensis; Diagram f-g: Simple circular-like pitted tracheid-fibres in Annona senegalensis 


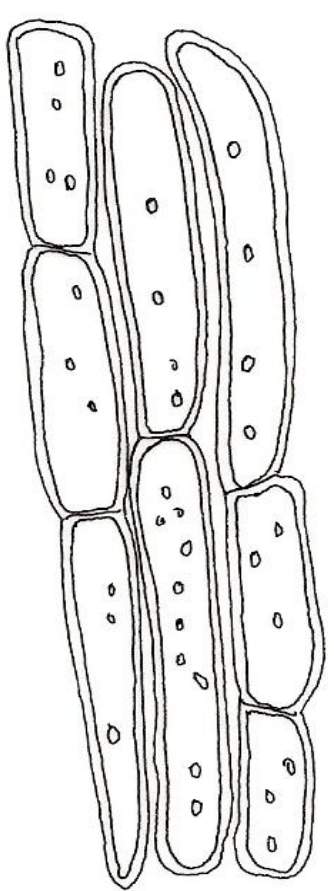

(a)

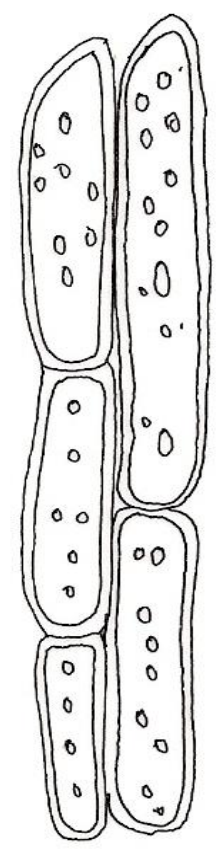

(c)
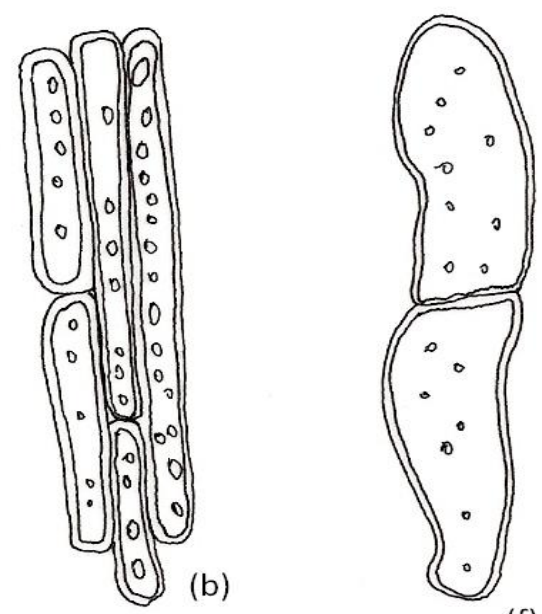

(f)

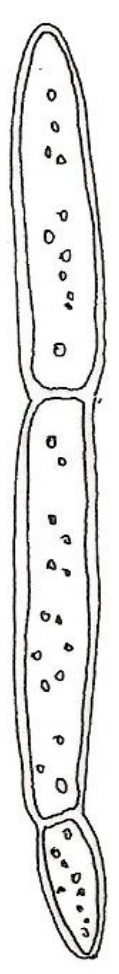

(d)

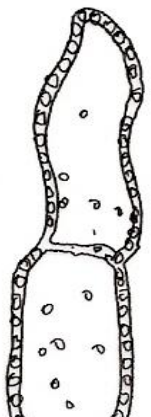

(e)

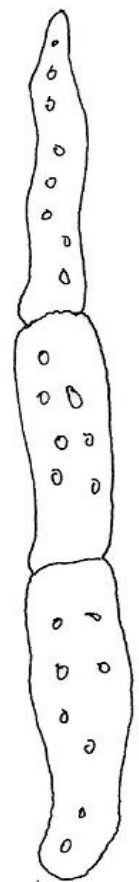

(h)

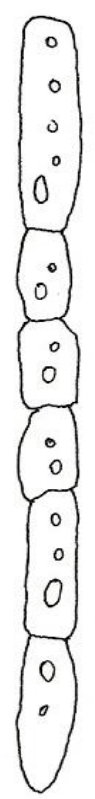

(g)

Fig. 3. Diagrammatic illustration of parenchyma cells of Annona senegalensis; Diagram a-c: Ray parenchyma cells in Annona senegalensis; Diagram d-h: Axial parenchyma cells in Annona senegalensis 


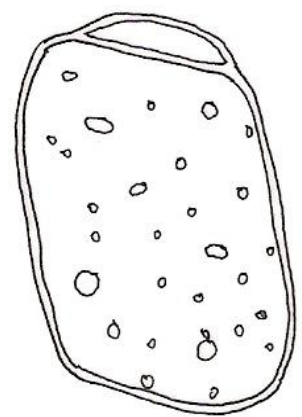

(a)

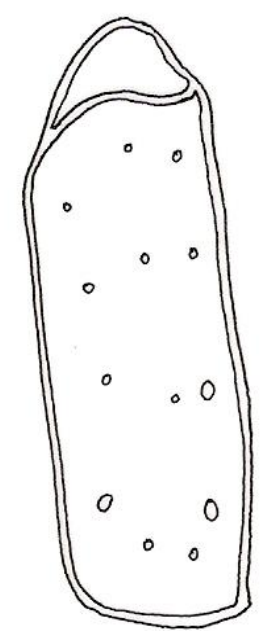

(b)

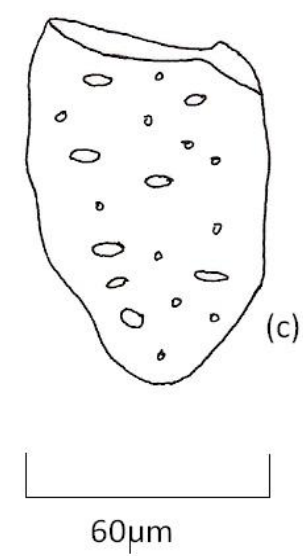

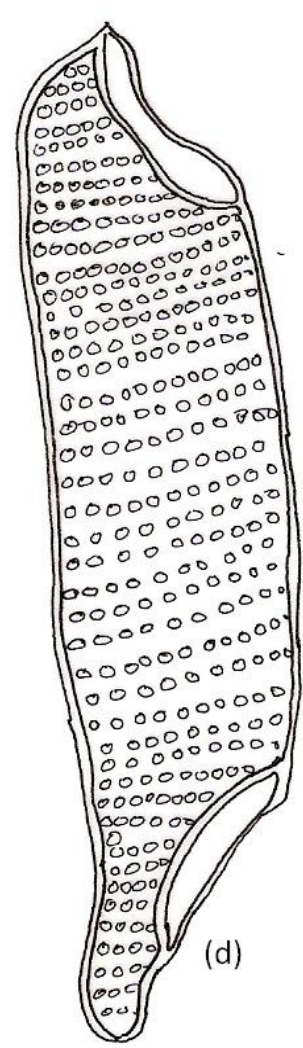

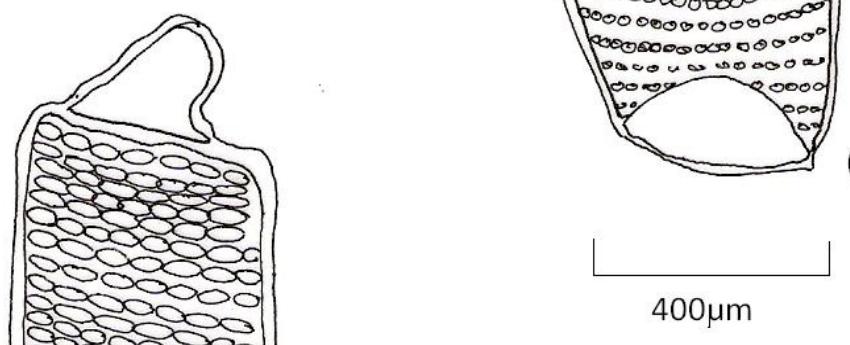

(e)

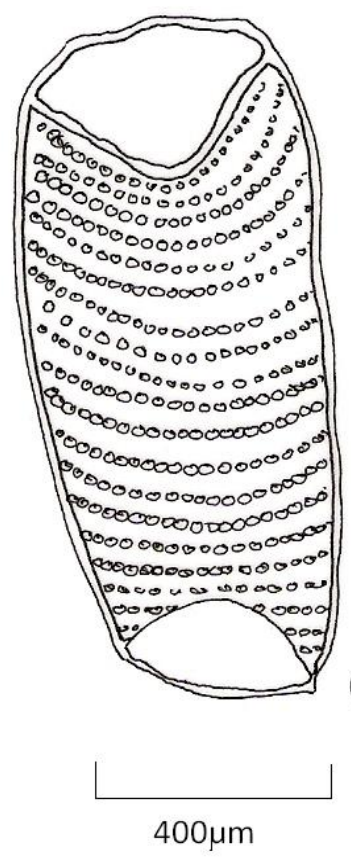

Fig. 4. Diagrammatic illustration of vessel member types of Annona muricata; Diagram a-c: Wide vessel types in Annona muricata; Diagram d-f: Narrow vessel types in Annona muricata 

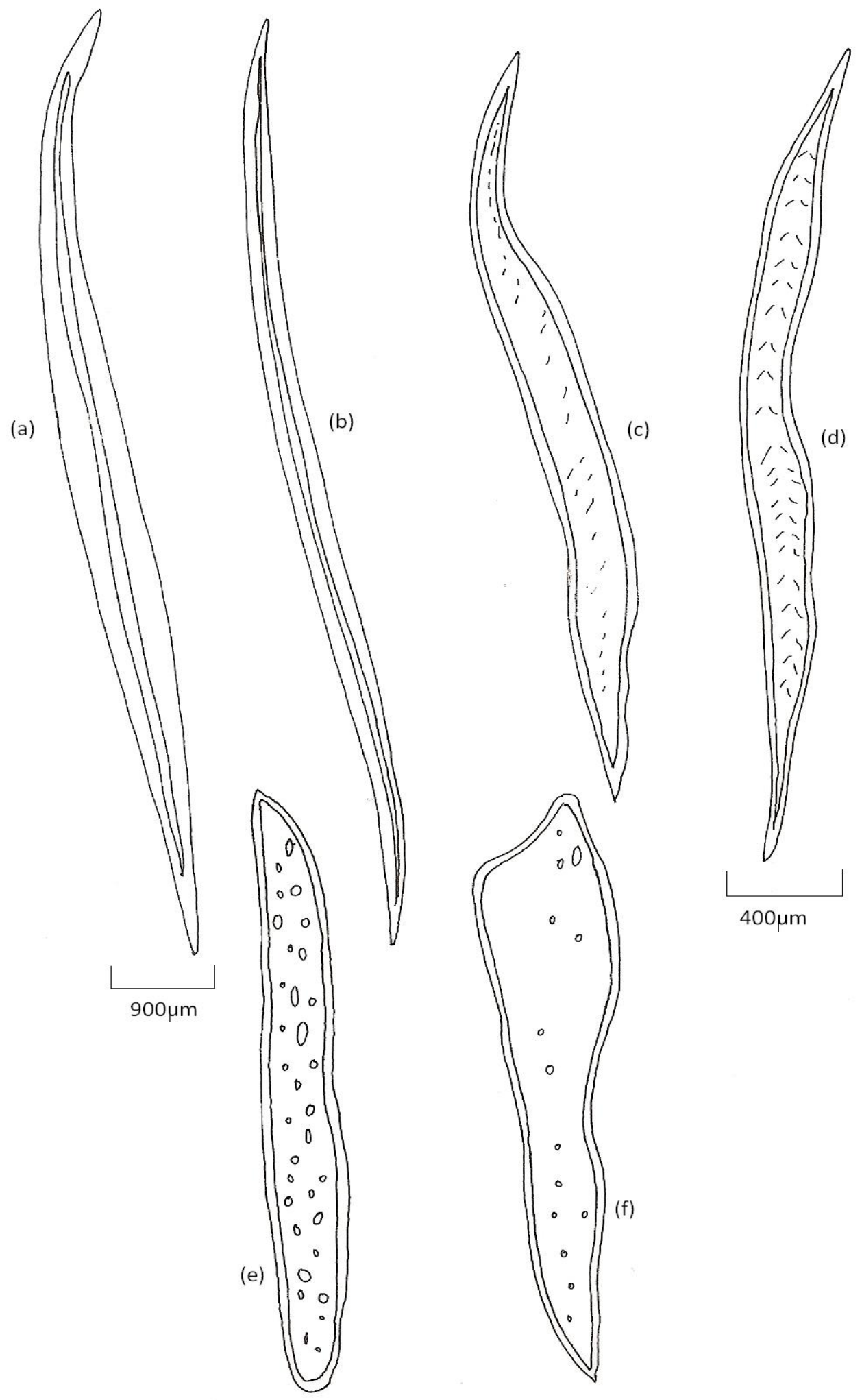

Fig. 5. Diagrammatic illustration of fibre types in Annona muricata; Diagram a-b: Libriform Fibres in Annona muricata; Diagram c-d: Simple slit-like pitted fibre-tracheids in Annona muricata; Diagram e-f: Simple circular-like pitted fibre-tracheids in Annona muricata 


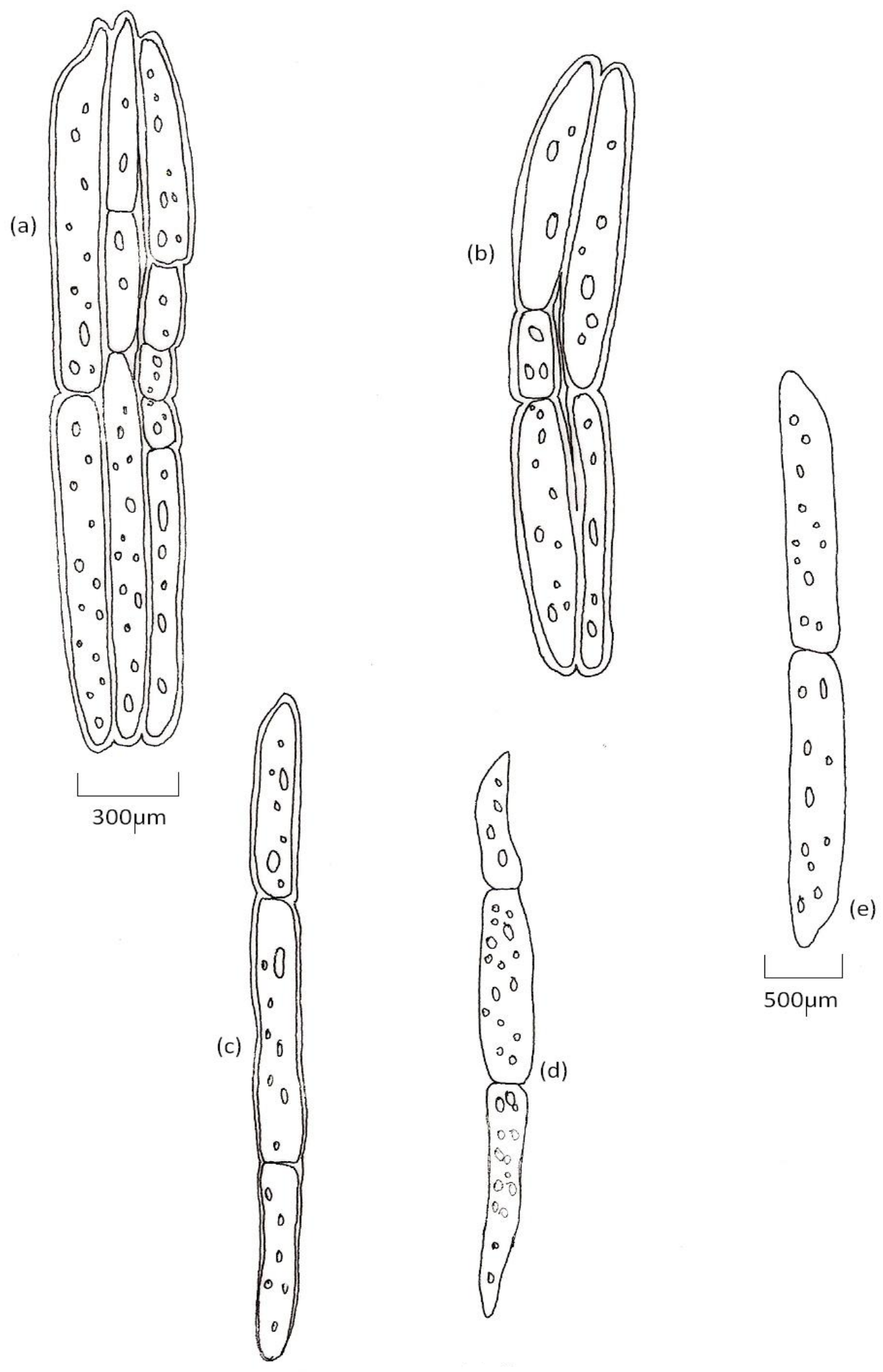

Fig. 6. Diagrammatic illustration of parenchyma cells in Annona muricata; Diagram a-b: Ray parenchyma cells in Annona muricata; Diagram c-e: Axial parenchyma cells in Annona muricata 


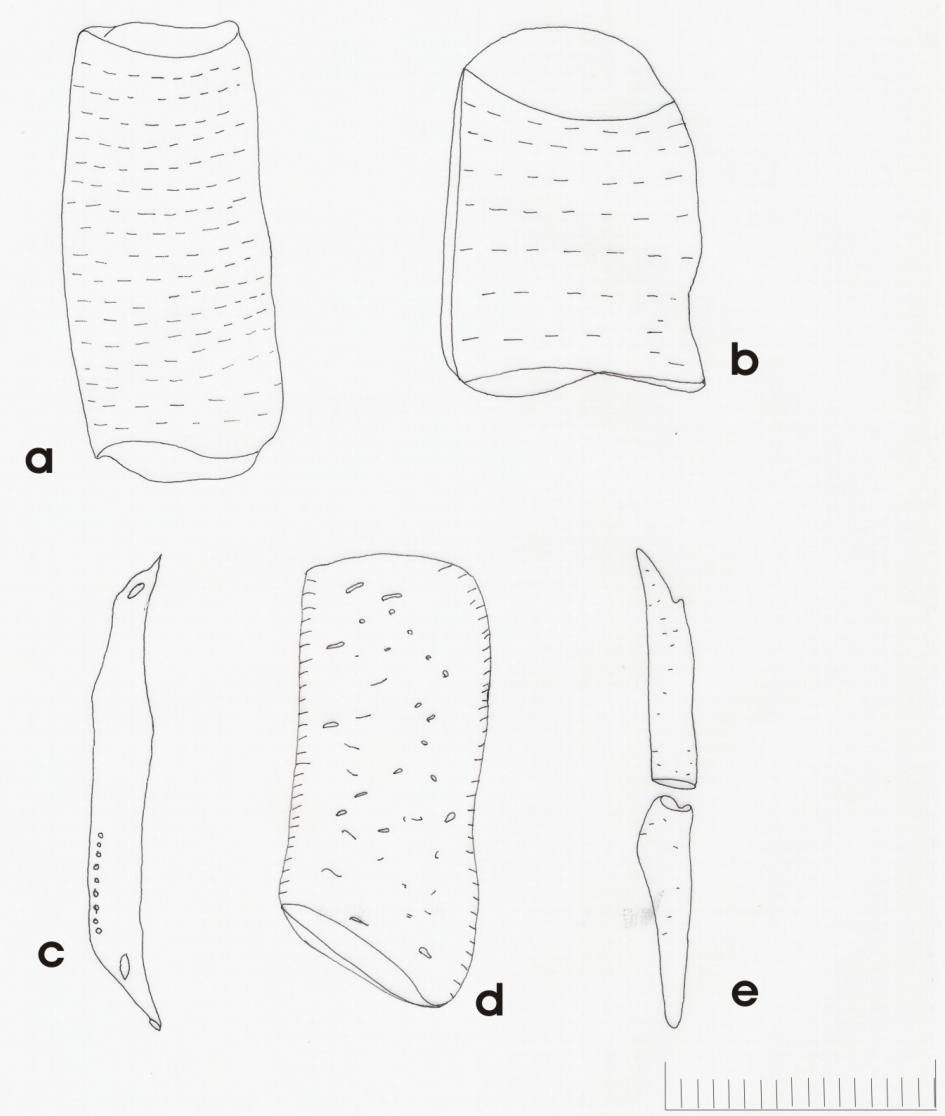

263. $1 \mu \mathrm{m}$

Fig. 7. Annona reticulata; Vessel Members: wide vessels (a, b and d) and narrow vessels (c and e)
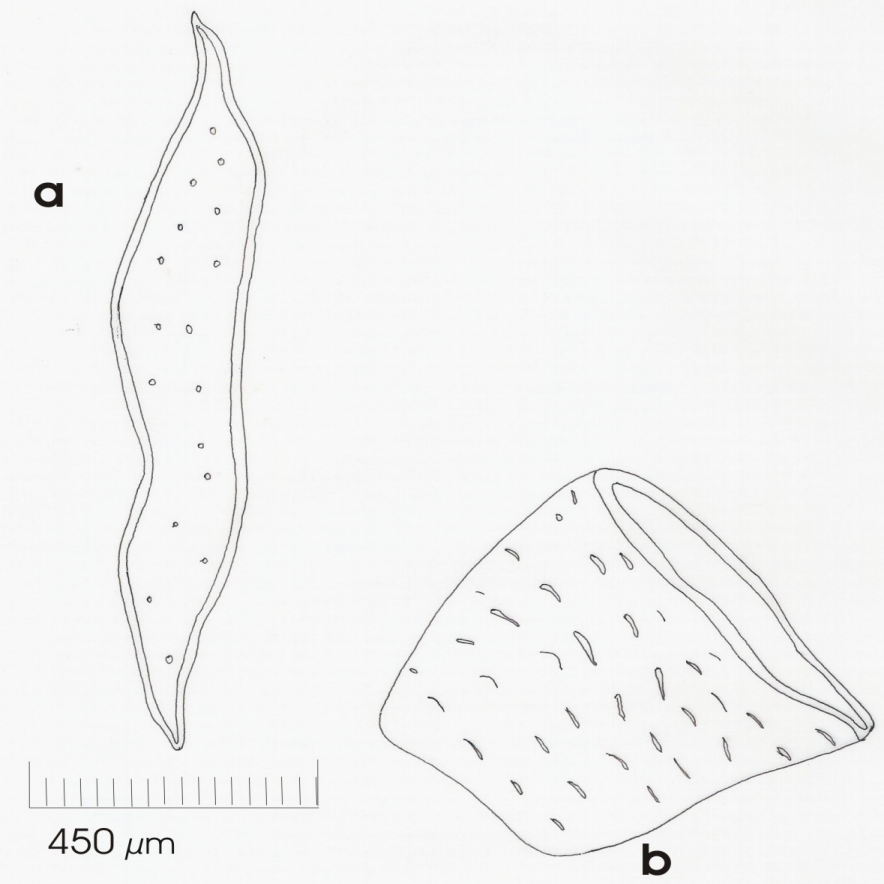

263. $1 \mu \mathrm{m}$

Fig. 8. Annona reticulata; (a) Fibre tracheids and (b) wide vessel 

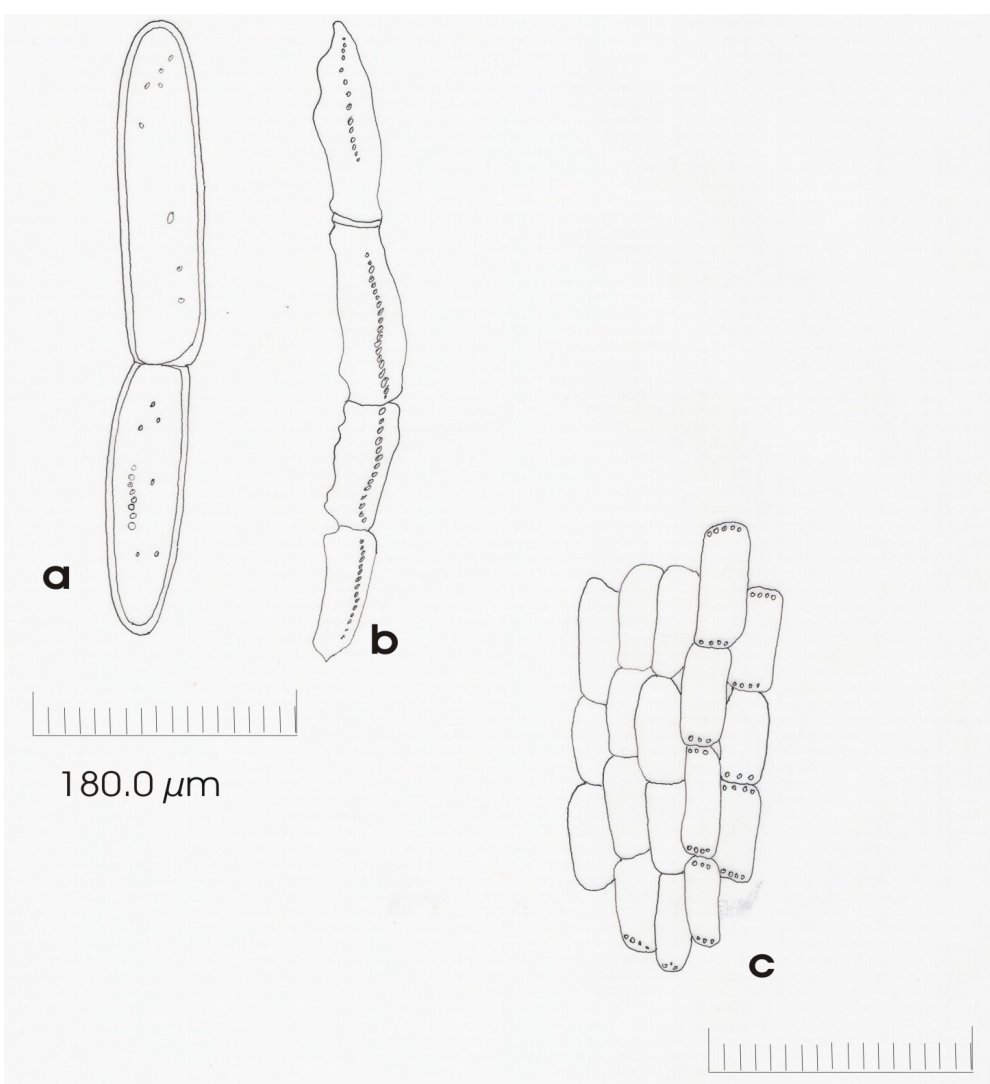

$72.0 \mu \mathrm{m}$

Fig. 9. Annona reticulata; Axial parenchyma strand ( $\mathrm{a}$ and $\mathrm{b}$ ) and ray parenchyma cells (c)

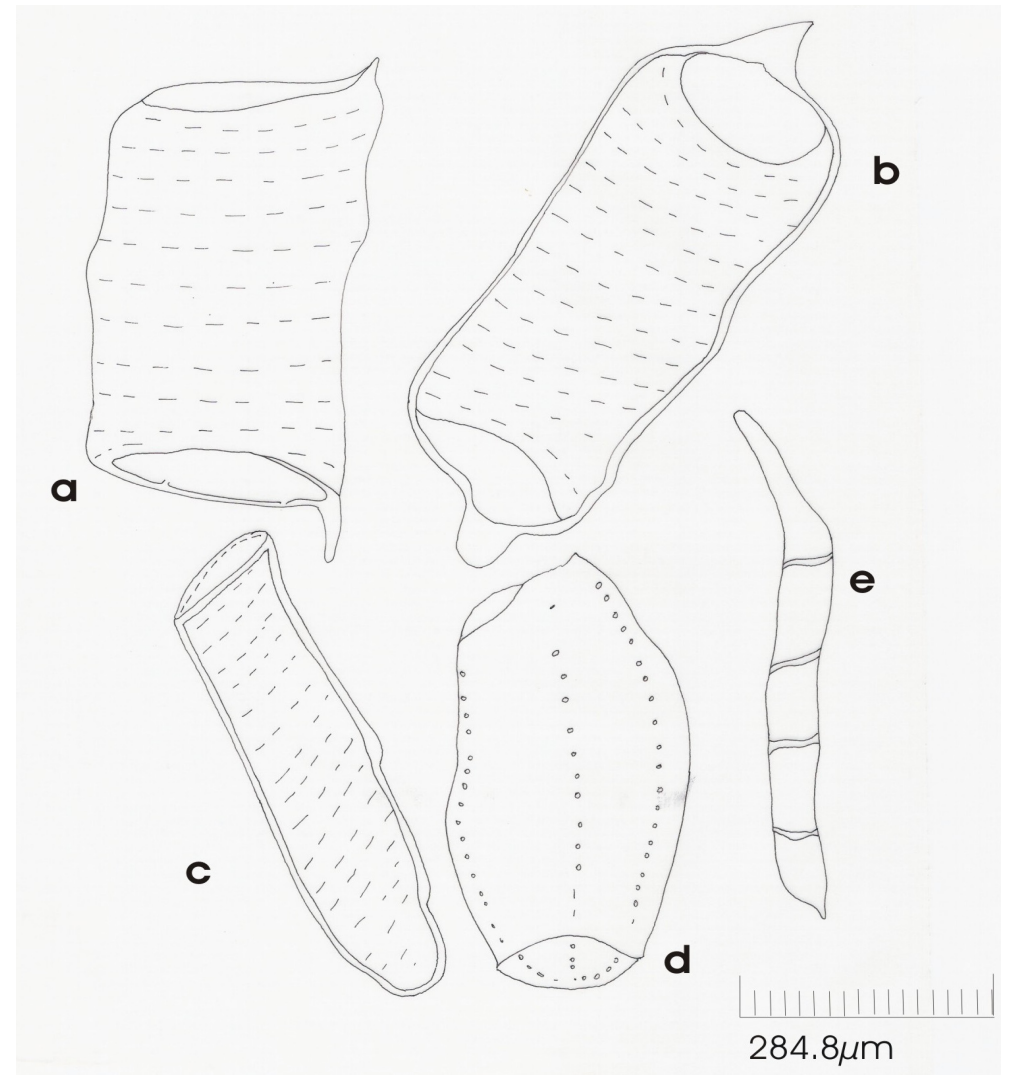

Fig. 10. Annona squamosa; Wide vessels (a, b and d) 


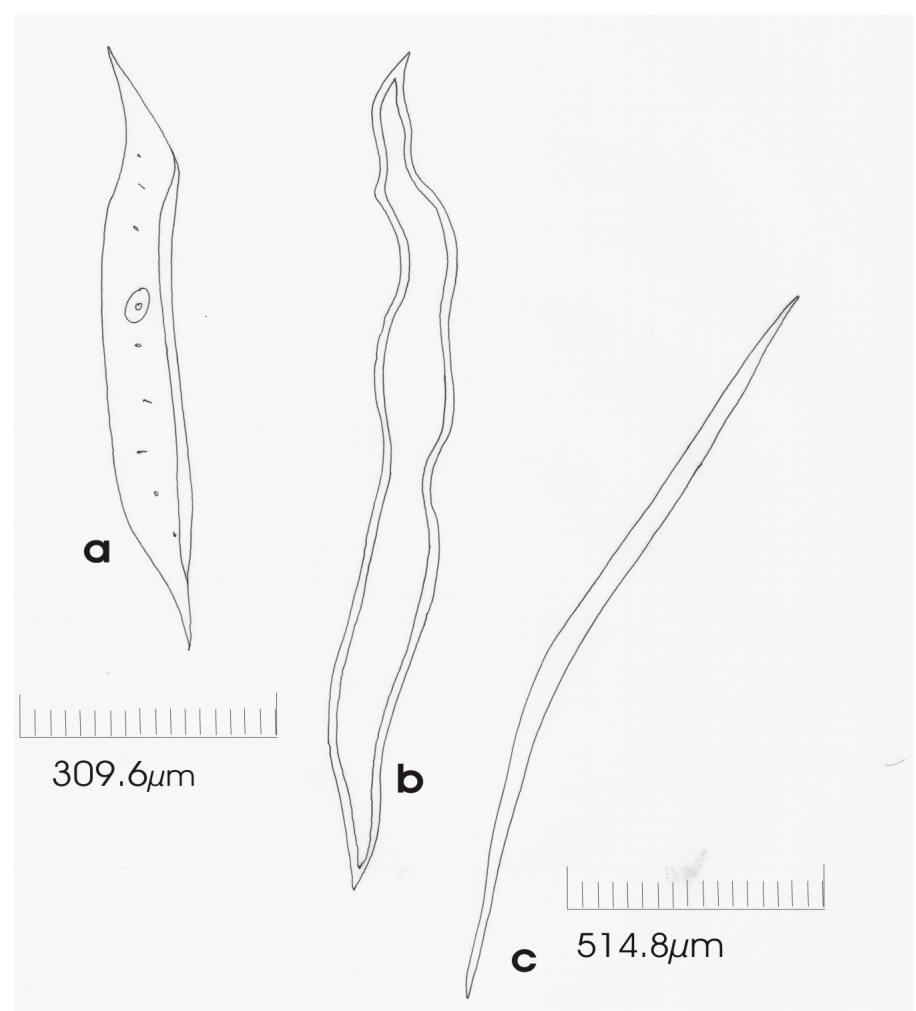

Fig. 11. Annona squamosa; Fibre tracheids (a and b) and libriform fibre (c)

more nutritional (protein) and shelf-life (Folorunso and Modupe, 2007). It may therefore be concluded that the earlier mentioned diagnostic characters conferred more nutritional value on them. The character that separates the two species is the presence of more fibres in $A$. reticulata than in $A$. squamosa. This may suggest the arborescence habit of $A$. reticulata while $A$. squamosa is fructicose.

The diagnostic feature for $A$. senegalensis is the occurrence of more vessels and the presence of axial parenchyma that is paratracheal. The higher number of vessels might be one of its diagnostic characteristics for adapting in the savanna. If one vessel is disabled by an air embolism due to water stress, neighbouring vessels may retain water columns and the conductive pathway remains intact.

In the present paper, wood anatomical characters of importance in the identification of the species of Annona have been reported and a taxonomic key for the identification of each of the species is hereby produced.

\section{References}

Folorunso AE, Modupe OV (2007). Comparative study on the biochemical properties of the fruits of some Annona species and their leaf architectural study. Not Bot Horti Agrobo 35(1):15-19

Folorunso AE, Olorode O (2006a). Crude protein electrophoresis of some species of Annona in Nigeria, Ife J Sci 8(1):15-18.

Folorunso AE, Olorode O (2006b). Biosystematic studies in Annonaceae I. Vegetative and Floral Morphological studies of some species of Annona in Nigeria. Res J Bot 1(3):118124.

International Centre for Underutilized Crops (2002). Fruits for the future, Annonaceae. Institute of irrigation and Development studies. University of Southampton, UK.

Nakasone HY, Paull RE (1998). Tropical Fruits. CAB International, Oxford.

Olatunji OA (1992). Comparative wood anatomy of some species of Zanthoxylum (Rutaceae) in Nigeria. Nigerian J Bot 5:1-14.

Salunkhe DK, Desai BB (1986). Postharvest Biotechnology of Fruits, CRC Press Inc. Florida, U.S.A.

Vogt KA (1995). Common Trees and Shrubs of Dryland Sudan. SOS Sahel International, London.

\section{Taxonomic Key for the identification of Annona species} studied

Axial parenchyma abundant and paratracheal; vessels abundant A. senegalensis

Axial parenchyma abundant, confluent paratracheal; vessels not abundant

A. muricata, $A$. reticulata and $A$ squamosa

Osteosclerids absent in the pith $A$. muricata

Osteosclerids present in the pith $A$. reticulata and $A$. squamosa
Fibres abundant
A. reticulata
Fibres not abundant
A. squamosa 